\title{
Economic Integration of Small and Medium Enterprise in Manufacturing Sector: The Case of Ethiopia, Tigray Regional State Mekelle City
}

\author{
Abrehet Mehari \\ Lecturer in Ethiopia Civil Service University, Ethiopia, Addis Ababa
}

\begin{abstract}
The purpose of this study is to assess the economic integration of small and medium enterprises (SMEs) in Tigray, Ethiopia. Focusing mainly on strategies, enabling environment, competitiveness, and challenges of the economic integration of SMEs. This study was employed in a cross-sectional mixed approach method. The data were collected using 148 samples based on proportional stratified sampling after a pilot test was managed and analyzed using SPSS. It presented using percentage, mean, standard deviation, and ordinary least squire regression model. Interviews with 15 leaders and stakeholders, 8 focus group discussions were conducted with the SMEs council and a non-participatory observation of the researcher. The result indicates that SMEs are operated by owners and families, which implies that contribution to employment and income generation for others is very limited. Access to finance, work promising, market linkage, and quality and quantity input were also the general challenge of all SMEs. Peace and security among Ethiopian Regions and the Ethio-Eriteria border, the dependency mentality and rent-seeking behavior of SMEs operators are other challenges of SMEs. Also, the commitment, attitude, and capacity of the leaders at a different level to support and coordinate SMEs is weak. Thus, policies and strategies should review and adjust considering the current political situation. Capacity building to operators and agency leaders are very critical. Finally, special financial institutions and market supporting unit should be established to help SME's competitiveness. Work promises and infrastructure should be ready before the SMEs was established. Keywords:Small and Medium Enterprise, Economic Integration of Small Enterprises, Challenges, Tigray, Ethiopia
\end{abstract}

DOI: $10.7176 / \mathrm{JESD} / 12-19-01$

Publication date:October $31^{\text {st }} 2021$

\section{Introduction}

The Government of Ethiopia has set several national development goals to be achieved by 2025. This includes, among others, attaining lower-middle-income status; diversifying and doubling the country's export capacity; lifting the contribution of the manufacturing sector from its current level of $5 \%$ to $17 \%$; turning Ethiopia into leading manufacturing hub in Africa and creating decent jobs and dynamic private sector that contribute to growth and structural transformation(Tegay,2018). The industrial sector in general, and the manufacturing sub-sector, in particular, is expected to play a pivotal role in attaining these goals and pave the way towards successful economic transformation. In a developing country like Ethiopia where capital and foreign exchange are scarce, and labor is relatively abundant, the most realistic and viable approach to kick-start industrialization and structural transformation is to initiate investment in SMEs manufacturing sub-sectors, especially those that rely on laborintensive production technology.

Thus, the development of SMEs in the manufacturing sector has been a big agenda on the Ethiopian Government as a means of generating employment and reduce poverty. A full fledge MSME Development Strategy was formulated in 1997 E, C (2004) to addressing the difficulties and promoting the growth and expansion of MSMEs and then revised in 2011 (MoTI,1997; FDRE, 2012). The Government established Federal in 1998 E.C(2005/6)(Proclamation 33/98) and Regional in 2001 E.C(2008) Micro and Small Enterprises Development Agency were stablished at Federal and Regional Leve to provide extension services to the sector at the federal and regional level(Belay 2000: CSA 2003; Mulatu 2005; Adil 2007; Mesfin,2015)

However, the government does not include Medium enterprise in the category which is too much recommendable to see the progress, and transitions of enterprises from Micro to Small and then to Medium which need the attention of the government to meet its aspiration of reaching the middle-income country by 2025(Amare, 2017).

SMEs an engine of economic growth (Charles, 2008; Tsegay, 2015; Amentie et al, 2016) jobs creation and poverty alleviation (World Bank, 2007; MoUDH, 2012; Cibela, 2016; Dawit 2017; Yared, 2018) seed and backbone of the private sector (Biru, Vugar et al., 2017), and a manifest of a thriving and dynamic economy which lay a fundamental foundation for the industrialized economy (MoUDH, 2012; Yared, 2018).In addition, SMEs are seen as a corner stone of national economies and significant contribution to the prosperity of a country through economic growth and employment creation(Harvie, Narjoko and Oum,2010) cited by Chuc,et al,2017.

Vakharia \&Yenipazarli, 2009 suggested that the process of economic integration has also opened 
opportunities and increased pressure for SMEs to expand their value and to form a strategic alliance with local or foreign firms to facilitate production and distribute their products in the global market. The Federal SMEs indicate that the Ethiopian government has created 700,000 jobs to 600.000 enterprises engaged in various activities through empowering SMEs in the first Growth and Transformation Plan (GDP I) and this number will be expected to reach 2.1 million in GDP II in 2019/20. From this 5022 SMEs are in Tigray Regional State and 1488 in Mekel City. Data indicated from the profile of the small and medium enterprise development agency office the total startup capital of 123 small enterprises were 348,940 and now it was growing to 40,564,241 birr out of this 3,196,700 birr from own ,272,700 from assistance and only 20,000 birr were from loan. Whereas 86 medium enterprise had started by 3,288,000 birr and increased to $32,100,000$ birr .however, as shown from the data the contribution of SMEs to job creation only 336 permanent and 295 temporary by small and 234 permanent and 376 temporary employees since 1997 their establishment (for the last fifteen years).Access to finance for medium enterprises were difficult since they were missed in the strategies. This will initiate debate among small and medium enterprise development agency, stakeholders and policy makers.

Eshetu and Mammo (2009) argue that "Ethiopia has failed to benefit from the phenomenal growth in the SMEs sector". This emerges from the fact that the sector lacks appropriate policy, to integrate into development strategy and sector-oriented support services agencies restrain the development and expansion of SMEs. Industry remained just 5 percent of GDP for most of the past decade. The country has not made significant progress in pulling labor out of agriculture into more productive and industrial jobs (report, 2015). This calls for urgent and systematic research on economic integration among SMEs' policies and strategies. This paper focused on the economic integration of SMEs in the manufacturing sub-sector engaged in wood and metal, Textile and Garment, Leather and Leather Product Agroprocessing and Construction Input manufacturing sub-sectors.

\section{Problem Statement}

Ethiopia is characterized as an undeveloped country, chronic poverty, with a high population second to Africa, lack of investment capital and have infant entrepreneurship are all persistent problems of the country (Elias,2015). Given this situation, we may not expect there is economic integration of SMEs and entrepreneurship as required and derived by SMEs members and actors at large.

World Bank Group 2015 mentioned that the private sector is expected to play a key role in Ethiopia's journey to become a lower middle-income country in 2025. However, Ethiopian firms face significant financial constraints, because financial institutions do not accommodate Small and medium enterprise needs. Addressing the Missing Middle Challenge, revealed that without adequate support from financial institutions, SMEs are not able to grow, or create more job opportunities.

As World Bank 's Investment Climate mentioned that SMEs as a fundamental foundation and seed for manufacturing industries. However, the quality, and coverage of infrastructure is low, the inadequacy stems largely from resource and capacity constraints leads most SMEs low productivity, and inefficient allocation resource that lacks SME's competitiveness. This is a major impediment to the expansion of production for SMEs, and the development of export capacity (CBC,2013).

The vision of Tigray is to create a society where extreme poverty becomes history and every citizen has access to a job. The regional government of Tigray now looking into the future and has embarked on development strategies aimed at transforming Tigray into the most dynamic and technology more advanced region in Ethiopia. But underdeveloped nature of productive capacity, absorbing unemployment into the productive sector is a challenge of the region (GSTS,2019). This makes difficult to strengthen the economic integration of SMEs in the manufacturing sector which calls systematic research in this area.

Research has been done in the area of micro and small enterprise. However, as per the knowledge of the researcher, studies in the field of the economic integration of SMEs in the manufacturing sector in Tigray Regional State have not been done before. Therefore, the main objective of this study is to assess the economic integration of Small and Medium Enterprises in manufacturing sector with a view of giving recommendation on ways to enhance sustainable development and increased economic growth of Tigray Regional State, Mekelle City.

\subsection{Objectives of the Study}

The general objective of this study is to examine the economic integration of small and medium enterprises in Ethiopia regarding the critical analysis of the manufacturing sector in Tigray Regional State.

Specific Objectives

1. To Analyze the implementation of the existing policies and strategies with economic integration

2. To Examine the practice of economic integration among SMEs in the manufacturing sector

3. To Explain the challenges of economic integration among SMEs in the manufacturing sector

\subsection{Research Questions}

1. How does the SMEs' policies and strategies are implemented in Tigray Regional State?

2. What is the practice of economic integration among SMEs in the manufacturing sector?

3. What are the underline factors that hinder the implementation of economic integration among SMEs? 


\section{Review of related literature Concept of Economic integration \\ 2.1 Definition of SMEs}

Ethiopia new Development Strategy published 2011E.C, was defined SMEs based on capital and Labor. Small enterprises are those with 6-30 workers and total capital, not exceeding 1.5 million Birr for manufacturing enterprise, while Medium enterprises have 31-100 workers with a total capital of less than 20 million Birr.

\subsection{Economic and integration theories}

Integration is the process of combining separate economies into a larger economic to bring sustainable growth of the country by utilization of all potential opportunities (Machlup et al,1977) cited by Amr Sadek et al, 2013, increase investment, sustainable demand, utilization of resources, and production efficiency (Marinov,1999; OECD,2018).Balassa (1995) also mentioned economic integration increased economic growth, improve access to advanced technology, way of communication, market structure, increased competition and uncertainty intended to lead lower prices for distributors and consumers. Additionally, it facilitates access to a larger consumer base and greater share of qualified workers (Hosny,2013). But increased exposure to competition, political risk, and limiting rules and regulations.

According to Margaret Lee,2014 economic integration creates common market and remove any trade barrier to have a regional cooperation and collaboration to free movement of production factors and working on equitable distribution of costs and benefits among countries (Lee 2003) cited by Dawit, 2017. However, economic integration and its benefits are not fully applicable to integration because of the challenge of competition, market access and free trade and Human resources capability (Meier, 1990; OECD,2004). The purpose of this paper is to assess the economic integration SMEs with relation to policies and strategies, its implementation and challenged along with.

\section{Competitiveness}

Competitiveness is a firms' capability to survive in the competition against its competitors. The factors that determine competitiveness are finance, human capital capacitates both in theory and practice, quality products demanded in the local and global market, a motivational system like tax and subsidies. if the above factors easy SMEs can be capable to produce high-quality products, and innovative to meet market demands. Regarding the access to a competitive market, SMEs can improve their production, change their market structure, and then increased their efficiency. Thus, the economic integration of SMEs is achieved in medium- and long-term objectives (Marinov,1999) but, Helleiner, 1999 argues that small and medium enterprises are an unequal partner who is forced to adjust to the economic and price structure in the larger market.

\section{Enabling Business Environment}

ADB (2014) mentioned that the Donor Committee for Enterprise Development (DCED) describes that business environment as the complex interplay of policies, laws, and regulations that affect business development in a given place and the institutions responsible for their enactment at the international, national, regional, and municipal level. A weak enabling business environment (legislation, policies, regulations, and support institutions) is the key constraint on the development of the SME sector. According to the ILO (2000) identified that institutional frameworks determine the effectiveness and efficiency of business infrastructures (business development skill, microfinance institutions, marketing, and research development). A good institutional framework enables access of these services to the needy with minimum cost whereas poor institutions in general, lead to higher transaction costs (ILO 2002; OECD, 2018) Ethiopia has also established a Federal and Regional Small and Medium Enterprise Developmental Agency at Federal (1998 E.C) and Regional (2000 E.C) level to support and coordinated SMEs (MoTI,2012). Though the registration was easy for SMEs, land registration, leasing, financing was difficult and bureaucratic in Ethiopia, Tigray for SMEs resulting in a high cost of compliance and low productivity but better for FDI. And weak SME skills and capacity, and their lack of access to markets, information, and technology have often been cited as common constraints.

The ILO has recently reviewed policy and regulatory environment in eight countries around the world as its global program, the policy review in Nepal has benefited from formulating an appropriate strategy from the international experience gained in such work in several countries and a reviewed the policies, legislation, and procedures; made an assessment of the MSEs business environment and their employer contribution; surveyed the MSEs, and a gap analysis (ILO, 2003).

\section{Methodology}

The study adopted a case study research design which is a cross-sectional mixed approach method in nature. Also, it employed a combined research approach (qualitative \& quantitative) to supplement data obtained in one approach with that of another and to provide a full picture of the issue under consideration. To attain the aim of this study, both qualitative and quantitative data were gathered from primary sources.

The study populations included 1448 operators of Small and medium enterprises from purposively selected 5 sub-sectors of the manufacturing sector. To carry out this study, 123 operators were selected through stratified sampling method after the pilot test was managed from December 2018toFebruary 2019, to determine the appropriateness and relevance of the questions in the instrument. For interview purposes, 15 small and medium 
enterprise development agency leaders and experts and stakeholders, 8 groups of SME council members were selected purposively for focus group discussions.

The researcher used both questionnaires (for quantitative data) and semi-structured interview questions for qualitative data. A focus group discussion was also employed. The data collected from primary sources and nonparticipatory observations were recorded, edited, organized, analyzed, interpreted and presented with research questions. The quantitative data were analyzed using descriptive statistical tools such as mean and standard deviations. p-value was presented by tables, whereas the description of findings was used for data collected through interviews and focus group discussions.

\section{Results and Discussions}

Reliability of the Instrument

According to Bryma \& Bell (2003), the Cronbach Alpha results use of an acceptable level of internal reliability. Therefore, the Cronbach's alpha coefficient was evaluated using the guidelines suggested by George and Mallery (2016) where, $>0.9$ (excellent), $>0.8$ (good), $>0.7$ (acceptable), $>0.6$ (questionable), $>0.5$ (poor), and $\leq 0.5$ (unacceptable). Hence, the items for the survey instrument had a Cronbach's alpha coefficient of $\alpha=0.81$, indicating good reliability. To maintain the validity, a comment of city and sub-city SMEs experts were consulted in providing comments. Additionally, for clarity of the instrument, the English version was translated into Tigrigna by having expert consultation. Hence, some confusing questions were modified.

Table 4.1: Demographic profile of respondents

\begin{tabular}{|c|c|c|c|c|}
\hline \multirow[t]{2}{*}{ № } & \multirow[b]{2}{*}{ Characteristics } & \multicolumn{3}{|c|}{ Respondents } \\
\hline & & Descriptions & Frequency & $\%$ \\
\hline \multirow[t]{3}{*}{ Sex composition } & 1 & Male & 69 & 71.9 \\
\hline & 2 & Female & 27 & 28.1 \\
\hline & & Total & 96 & 100.0 \\
\hline \multirow[t]{5}{*}{ Age } & 1 & $15-29$ & 16 & 16.7 \\
\hline & 2 & $30-49$ & 56 & 58.3 \\
\hline & 3 & $50-65$ & 21 & 21.9 \\
\hline & 4 & Above 65 & 3 & 3.1 \\
\hline & & Total & 96 & 100.0 \\
\hline \multirow[t]{6}{*}{ Level of education } & 1 & Illiterate & 10 & 10.4 \\
\hline & 2 & 1- 8 complete & 19 & 19.8 \\
\hline & 3 & 9-12 complete & 19 & 19.8 \\
\hline & 4 & Diploma & 29 & 30.2 \\
\hline & 5 & Degree above & 19 & 19.8 \\
\hline & & Total & 96 & 100.0 \\
\hline
\end{tabular}

As shown in Table 4.2, most of the respondents were male $(71.9 \%)$ and female were $(28.1 \%)$. This indicates that there is a gap between the two genders that lack creating a favorable condition to enable women to participate in SME activities and share the benefit from the development opportunities even though the government policy clearly stated that priority given to women youth.

Regarding the age structure of the business owners, 58.3\% of respondents were in the 30-49 age group, while $21.9 \%$ of the respondents were in the 50-65 years age group. Age groups 15-29 and above 65 years constitute $16.7 \%$ and $3.1 \%$ of respondents respectively. As stated above the government policies and strategies give emphasize to women and youth to engaged in SMEs. However the result shows that the active sections of the societies of both sexes do not benefit from the SME manufacturing sector, which is stated in the main objective of the manufacturing and urban development strategies (MOFED, 2006).

The respondents' level of education status is presented in Table 4.2. Most of the respondents (30.2\%) have diploma followed by equally (19.8\%) 1-8 complete, 9-12 complete and (degree and above), while (10.4\%) are illiterate. This is, of course, the manufacturing industry is a means to create employment opportunities and economic growth. This indicates most of the respondents had an educational background diploma. The sector could not absorb and create a job for the new blood graduated productive forces coming from different Universities to use new knowledge and technology. This should be further integrated into different development agenda since it is critical for the peace and security of the country. Motivate and aware to organize themselves based on their demand /willingness in an association to become benefit from credit facilities, provision of land and shads in the city.

Regarding the income of SMEs operators, 31.7\% of the respondents said SMEs earn 501-1000 Birr; while $25.5 \%$ have earned less than 500 Birr. 17.9\%, 13.1\%, and the rest 11.7\% are 1001-1500 Birr, 1501-2000 Birr, and greater than 2000 birr earn respectively. Though most of the SMEs have earned the highest 1000-birr (almost \$35) income, countries like Ethiopia suffer from inflation (around 19\%). Thus, the business cannot make a difference to change the living standard of the people, it is below the standard income per capita is $\$ 65$ per month. To 
triangulate this, result an interview was heled with SMEDA leaders. The result of the interviewed shows that most of SMEs were hiding their income in order avoid and evade tax. But data indicated from the profile of the SMESDA office the total capital of the 123 small enterprises start-up 348,940 and now it was growth to 40,564,241 birr out of this 3,196,700 birr own and 272,700 from assistance and only 20,000birr were from loan. Whereas the 86 medium enterprise had started by $3,288,000$ birr and increased to $32,100,000$ birr

As seen from the data, most of the respondents $37.5 \%$ were engaged in metal and woodwork, $28.1 \%$ textile and garment, leather products $21.9 \%$ construction input industry and those who are from agro-processing $12.5 \%$ chemical and mining $6.75 \%$. The sector that dominates in the operation of the small and medium manufacturing enterprises is metal and woodwork and textile and garment, leather products the second and third place also goes to the construction manufacturing and geoprocessing sector respectively. This implies most of the SME engaged in metals and woodwork using past own experience and local skill and technology and focus on the local market. This implies the sector lacks scientific knowledge and skill to design and produce quality products compete in the international market.

Concerning the source of funds to start-up business on the same table; most of $40.6 \%$ were from microfinance institutions and $39.6 \%$ their saving and $16.7 \%$ from their family, whereas those of $3.1 \%$ from other sources like credit associations and bank. This shows that the main source of finance for SMEs in the city is from microfinance institutions and personal savings to start their business. The result from interviewee shows that access to finance from the government finical institutions is difficult and bureaucratic.

Most of the enterprises $71.9 \%$ is small manufacturing while the rest of the sample $28.1 \%$ of the respondent enterprises are in the category of medium manufacturing. This implies less attention and effort to initiate promote the small enterprises to come up and grow to the next stage and missed the middle elements to support. In addition to this the capital limit of the enterprises high and lack of team sprit to establish together. Due to their small size lack sound experiences and financial position are less capable of adjusting and carrying on successful businesses to upgrade to the next stage. Furthermore, prevent them from participating in the global market.

\begin{tabular}{|c|c|c|c|c|c|c|c|}
\hline Table 4.2 Related policies and Strategies & & $\begin{array}{l}\text { strongly } \\
\text { disagree }\end{array}$ & disagree & undecided & agree & $\begin{array}{l}\text { strongly } \\
\text { agree }\end{array}$ & Mean \\
\hline Are the policies and strategies applicable to & Count & 16 & 16 & 24 & 40 & 27 & 3.37 \\
\hline SMEs & $\begin{array}{l}\text { Row } \\
\text { Valid N \% }\end{array}$ & 13.0 & 13.0 & 19.5 & 32.5 & 22.0 & \\
\hline Are the policies and strategies flexible and & Count & 19 & 15 & 25 & 44 & 20 & 3.25 \\
\hline ready to amend & $\begin{array}{l}\text { Row } \\
\text { Valid N \% }\end{array}$ & 15.4 & 12.2 & 20.3 & 35.8 & 16.3 & \\
\hline The policies and strategies were design & Count & 13 & 29 & 28 & 34 & 18 & 3.12 \\
\hline based on the regional context & $\begin{array}{l}\text { Row } \\
\text { Valid N \% }\end{array}$ & 10.7 & 23.8 & 23.0 & 27.9 & 14.8 & \\
\hline The policy contributes to the living hood & Count & 18 & 30 & 25 & 36 & 12 & 2.95 \\
\hline improvement of SMEs & $\begin{array}{l}\text { Row } \\
\text { Valid N \% }\end{array}$ & 14.9 & 24.8 & 20.7 & 29.8 & 9.9 & \\
\hline Financial policy of the country affects the & Count & 11 & 29 & 32 & 30 & 19 & 3.14 \\
\hline operating activities of SMEs & $\begin{array}{l}\text { Row } \\
\text { Valid N \% }\end{array}$ & 9.1 & 24.0 & 26.4 & 24.8 & 15.7 & \\
\hline Strategies were favor for large scale & Count & 9 & 35 & 38 & 27 & 12 & 2.98 \\
\hline enterprise than SMEs & $\begin{array}{l}\text { Row } \\
\text { Valid N \% }\end{array}$ & 7.4 & 28.9 & 31.4 & 22.3 & 9.9 & \\
\hline Strategies promote productivity of SMEs & Count & 15 & 42 & 29 & 23 & 13 & 2.81 \\
\hline & $\begin{array}{l}\text { Row } \\
\text { Valid N \% }\end{array}$ & 12.3 & 34.4 & 23.8 & 18.9 & 10.7 & \\
\hline Strategies promote entrepreneur and human & Count & 13 & 49 & 19 & 26 & 15 & 2.84 \\
\hline capital & $\begin{array}{l}\text { Row } \\
\text { Valid N \% }\end{array}$ & 10.7 & 40.2 & 15.6 & 21.3 & 12.3 & \\
\hline the policies are offer utmost attention to & Count & 11 & 45 & 22 & 16 & 14 & 2.79 \\
\hline SME & $\begin{array}{l}\text { Row } \\
\text { Valid N \% }\end{array}$ & 10.2 & 41.7 & 20.4 & 14.8 & 13.0 & \\
\hline
\end{tabular}

There is a significant difference among mean score indicators of Related Policies and Strategies Implementation. Strategies promote entrepreneur and human capital, Strategies promote productivity of SMEs and the policies are offered utmost attention to SME depict that the mean and standard deviation of $(\bar{X}=2.81$, S.D $=1.21, \bar{X}=2.84, \mathrm{~S} . \mathrm{D}=1.22$ and $\bar{X}=2.79, \mathrm{~S} . \mathrm{D}=1.14)$ respectively low because all the items have scored 
below the average mean 2.97 . Moreover, the majority $46.7 \%$ of the respondents agreed that the strategies do not promote entrepreneur and human capital, $50.9 \%$ productivity of SMEs and $51.9 \%$ as well as offer utmost attention to SME rather priority is given to micro, large enterprises, and foreign direct investment.

This question was also supplemented with interviews with the SMEs leaders and stakeholders and discussion with SMEs councils whether the strategy applies to SMEs' operation or not. They said that these policies and strategies are important to get out of poverty if it implements properly. But it lacks proper implementation because of different reasons (lack of scientific knowledge and skills to understand the federal strategies commitment of the leaders) especially at the low-level position and experts to support and coordinate SMEs' activities. On the other hand, SMEs are the missing element in 1997 E.C strategies, no support to middle enterprises in the strategies especially with related to finance rather focus on micro and large-scale enterprises. The linkage of SMEs Strategy with other sectors are very poor even though the interest of the government is very high due to the lack of action of government officials and less effort by SMEs hence, this time SMEs are not protected from the new trade agreement signed by Ethiopia because they are not competing in the international market due to lake of resources and technology. these require the government's adequate support to SMEs.

Table 4.3 Enabling environment \begin{tabular}{|l|l|l|l|l|l} 
strongly & strongly \\
\hline
\end{tabular}

\begin{tabular}{|c|c|c|c|c|c|c|c|c|}
\hline \multirow{2}{*}{$\begin{array}{l}\text { Have adequate knowledge of SME } \\
\text { strategy to support SMEs }\end{array}$} & \multicolumn{2}{|l|}{ Count } & 15 & 49 & 25 & \multicolumn{2}{|l|}{16} & 2.78 \\
\hline & $\begin{array}{l}\text { Row } \\
\text { N \% }\end{array}$ & Valid & 12.2 & 39.8 & 20.3 & 13.0 & 14.6 & \\
\hline \multirow[t]{2}{*}{ Working environment conductive } & Count & & 20 & 40 & 33 & 20 & 10 & 2.67 \\
\hline & $\begin{array}{l}\text { Row } \\
\text { N \% }\end{array}$ & Valid & 16.3 & 32.5 & 26.8 & 16.3 & 8.1 & \\
\hline \multirow{2}{*}{$\begin{array}{l}\text { Provision of supporting SMEs to get } \\
\text { business development skills }\end{array}$} & Count & & 21 & 40 & 28 & 23 & 11 & 2.70 \\
\hline & $\begin{array}{l}\text { Row } \\
\text { N \% }\end{array}$ & Valid & 17.1 & 32.5 & 22.8 & 18.7 & 8.9 & \\
\hline \multirow{2}{*}{$\begin{array}{l}\text { Provision of facilitating SMEs to get } \\
\text { finance }\end{array}$} & Count & & 24 & 44 & 28 & 23 & 3 & 2.48 \\
\hline & $\begin{array}{l}\text { Row } \\
\text { N \% }\end{array}$ & Valid & 19.7 & 36.1 & 23.0 & 18.9 & 2.5 & \\
\hline \multirow{2}{*}{$\begin{array}{l}\text { Provision of helping SMEs to get } \\
\text { working promise/place }\end{array}$} & Count & & 21 & 49 & 30 & 17 & 6 & 2.50 \\
\hline & $\begin{array}{l}\text { Row } \\
\text { N \% }\end{array}$ & Valid & 17.1 & 39.8 & 24.4 & 13.8 & 4.9 & \\
\hline \multirow{2}{*}{$\begin{array}{l}\text { Provision of facilitation to create market } \\
\text { linkage for SME }\end{array}$} & Count & & 18 & 54 & 28 & 14 & 9 & 2.53 \\
\hline & $\begin{array}{l}\text { Row } \\
\text { N \% }\end{array}$ & Valid & 14.6 & 43.9 & 22.8 & 11.4 & 7.3 & \\
\hline
\end{tabular}

One of the roles of implementing the strategy is creating a conducive working environment in which operators would grow and develop. The conducive environment helps them operate efficiently and grow their businesses with the broader purpose of contributing to economic growth, employment generation, and poverty alleviation. Public sector leaders are responsible for creating a conducive and attractive working environment in their organizations. The existence of market linkage between enterprises, domestic and international markets helps enterprises to distribute their products (MoUDH 2016). Berhun et al., (2014) also indicated that the existence of a strong supportive government institution helps to search the new market, demand forecasting, and market information

Though the government design strategy to support the small and medium enterprises, the result shows the mean value of creating a conducive working environment regarding facilitation to get finance $(\bar{X}=2.44$, $\mathrm{S} . \mathrm{D}=0.986$, working premises, $\bar{x}=2.45, \mathrm{~S} . \mathrm{D}=0.983$ and market linkage with others $\bar{X}=2.47$ and $\mathrm{S} . \mathrm{D}=0.973$ is felt below average 2.55. And most of the respondents were agreed that no conducive environment was available for economic integration of SMEs created by the regional governments even though initiation is there. This implies that the city lacks commitment and serious attention in creating a conducive working environment and applied the best experience taken from other successful countries using the existing resources.

The interview results also supported the above idea SMEs are working in difficulty since the failure in creating an enabling business environment. The strategic implementation has faced a problem starting from the establishment of SMEs. No proper study was conducted before the SMEs are established such as the criteria, who support them? does the supporting unit have the capacity in knowledge, skill and administrative system better than the SMEs? Does SMEs willing to work as a team or independent? Most of the supporting bodies were graduated from TVET and they are teachers who have not to get fringe benefits to support the SMEs. Due to this reason the office had stopped to establishes SMEs for a year and act until it clears the mandate and supporting mechanism by the experts. The expert's knowledge and skills are not better than /below/ the SME operators. This situation makes 
the environment discouraging and implementers cannot strive with full potentials in promoting SMEs. Additionally, all the discussants were identified that the role of leaders is limited with poor coordination of responsible sectors, improper functioning of the council, and a great lack of contribution in establishing a suitable environment for the SMEs in accessing current information, providing a favorable working place and attractive market opportunity.

From the result shown above, one can deduce that the leader's role in creating a conducive working environment is weak. This problem might emanate from a lack of shared vision towards the role of SMEs in employment creation, economic growth, poverty alleviation, and economic integration. There might be also insufficient resources for the sector. Leadership needed to fill the gaps in creating a conducive working environment. Generally, the lack of encouraging policy and strategies and financial institutions. creating an enabling environment helps to develop business service which can ultimately help SMEs join regional or global supply chains, which bring new knowledge, skills and networks.

There is no significant difference among the mean score of the Practice of Economic Integration among SMEs in the MS indicators. The whole indicators or their mean depicts that the respondents are indifferent between disagreeing and undecided on those issues listed as an indicator. This implies that the government cannot create an enabling environment to understand the federal strategy to support the implementors in the provision of access to finance, working place and the market for SMEs operators. This can lead to low productivity and lack of completion in the market due to quality input emanate from insufficient finance. This in turn shortage of input to enforce interruption of production especially like construction input and lack of quality input to produce a quality product which is limited in the local market.

Table 4.4 Competitiveness

\begin{tabular}{|c|c|c|c|c|c|c|c|c|}
\hline & & & disagree & disagree & undecided & agree & agree & Mean \\
\hline \multirow[t]{2}{*}{ Available of skilled manpower } & Count & & 11 & 20 & 34 & 47 & 9 & 3.19 \\
\hline & $\begin{array}{l}\text { Row } \\
\text { N \% }\end{array}$ & Valid & 9.1 & 16.5 & 28.1 & 38.8 & 7.4 & \\
\hline \multirow[t]{2}{*}{ Available of cheap manpower } & Count & & 7 & 12 & 36 & 53 & 14 & 3.45 \\
\hline & $\begin{array}{l}\text { Row } \\
\text { N \% }\end{array}$ & Valid & 5.7 & 9.8 & 29.5 & 43.4 & 11.5 & \\
\hline \multirow[t]{2}{*}{ Available of infrastructure } & Count & & 16 & 39 & 33 & 29 & 5 & 2.74 \\
\hline & $\begin{array}{l}\text { Row } \\
\text { N \% }\end{array}$ & Valid & 13.1 & 32.0 & 27.0 & 23.8 & 4.1 & \\
\hline \multirow{2}{*}{$\begin{array}{l}\text { SMEs have produced domestic } \\
\text { demand of products }\end{array}$} & Count & & 11 & 39 & 25 & 39 & 8 & 2.95 \\
\hline & $\begin{array}{l}\text { Row } \\
\text { N \% }\end{array}$ & Valid & 9.0 & 32.0 & 20.5 & 32.0 & 6.6 & \\
\hline \multirow{2}{*}{$\begin{array}{l}\text { SMEs have produced external demand } \\
\text { of product }\end{array}$} & Count & & 18 & 49 & 29 & 20 & 6 & 2.57 \\
\hline & $\begin{array}{l}\text { Row } \\
\text { N \% }\end{array}$ & Valid & 14.8 & 40.2 & 23.8 & 16.4 & 4.9 & \\
\hline \multirow{2}{*}{$\begin{array}{l}\text { SMEs have capability to produce high } \\
\text { quality product }\end{array}$} & Count & & 21 & 51 & 19 & 25 & 6 & 2.54 \\
\hline & $\begin{array}{l}\text { Row } \\
\text { N \% }\end{array}$ & Valid & 17.2 & 41.8 & 15.6 & 20.5 & 4.9 & \\
\hline \multirow{2}{*}{$\begin{array}{l}\text { SMEs have competitive strategy to } \\
\text { compete in the market }\end{array}$} & Count & & 21 & 47 & 22 & 27 & 5 & 2.57 \\
\hline & $\begin{array}{l}\text { Row } \\
\text { N \% }\end{array}$ & Valid & 17.2 & 38.5 & 18.0 & 22.1 & 4.1 & \\
\hline \multirow{2}{*}{$\begin{array}{l}\text { Government incentives (tax redaction } \\
\text { subsidy and training of SMEs) }\end{array}$} & Count & & 19 & 45 & 19 & 26 & 11 & 2.71 \\
\hline & $\begin{array}{l}\text { Row } \\
\text { N \% }\end{array}$ & Valid & 15.8 & 37.5 & 15.8 & 21.7 & 9.2 & \\
\hline \multirow{2}{*}{$\begin{array}{l}\text { Availability of quantity and quality of } \\
\text { raw material/input }\end{array}$} & Count & & 24 & 40 & 21 & 25 & 12 & 2.68 \\
\hline & $\begin{array}{l}\text { Row } \\
\text { N \% }\end{array}$ & Valid & 19.7 & 32.8 & 17.2 & 20.5 & 9.8 & \\
\hline
\end{tabular}

SME competitiveness can be enhanced with strategies including proximity to resources and suppliers, shared infrastructure and knowledge exchange (UN,2012), as shown the data in the above table, there is a statistically significant difference among the mean score of competitiveness factors. Except for the availability of skilled manpower $(\bar{x}=3.18)$, available of cheap manpower $(\bar{X}=3.45)$ and SMEs have produced domestic demand of products $(\bar{X}=2.95)$, all the results on the above table are below average 2.90 . The respondents are indifferent between disagreeing and undecided on the rest of the indicators explained in the above table. Countries like Ethiopia, available cheap and skilled labor for SMEs are obvious. SMEs cannot absorb the available workforces in the sector and pay less cost for human labors, in turn, increase productivity, On the other hand, SMEs were not 
produced a quality material compete in the international market due to lack of competitive strategies, quality and quantity inputs and the government motivation at large. The respondents also disagreeing against $45 \%$, availability of infrastructure, $41 \%$ SMEs have produced domestic demand of products, 55\% SMEs have produced external demand of product, 59\% SMEs can produce high-quality product, 55.7\% SMEs have competitive strategy to compete in the market, $53.3 \%$ government incentives (tax redaction subsidy and training of SMEs), and 52.5\% availability of quantity and quality of raw material/input. Whereas, $46.2 \%$ and $54.9 \%$ the respondents were agreeing that the availability of skilled manpower and availability of cheap manpower. Small and medium enterprise development agency helps SMEs to get out of dependent and create a link themselves with the local and national market. Aware SMEs' work given to them is only and only through competitive bidding and prepare contract agreement based on business priority. Moreover, motivate SMEs to participate in bazar and exhibition promoting their product and create a link with local and foreign market enterprises. Established a system empowering SMEs to participate in federal manufacturing industries by sending their products to sell in the federal and international markets. Training is given to SMEs two times a year on the quality and quantity standard required for a foreign market. However, the respondent said SMEs were always dependent on the government to arrange market and promote their product and prepare business cards and promote themselves and create a link with local and international markets. They limited in the local market. This implies a lack of market assessment based on study knowing demanded products by the local and international markets. Moreover, the gap in technology transfer, capital, market linkage exposure to foreign market and management system since they used family employees. Further, unwillingness to take risk of producing quality products and fear of increasing cost of production and lack of internationalization outlook.

Table 4.5 Challenges of SMEs

\begin{tabular}{|c|c|c|c|c|c|c|c|c|}
\hline & & & disagree & disagree & undecided & agree & agree & Mean \\
\hline \multirow{2}{*}{$\begin{array}{l}\text { There is adequate support service of } \\
\text { training provision }\end{array}$} & Count & & 23 & 31 & 22 & 25 & 21 & 2.92 \\
\hline & $\begin{array}{l}\text { Row } \\
\text { N \% }\end{array}$ & Valid & 18.9 & 25.4 & 18.0 & 20.5 & 17.2 & \\
\hline \multirow{2}{*}{$\begin{array}{l}\text { There are adequate support service of } \\
\text { work place provision }\end{array}$} & Count & & 26 & 33 & 30 & 20 & 12 & 2.66 \\
\hline & $\begin{array}{l}\text { Row } \\
\text { N \% }\end{array}$ & Valid & 21.5 & 27.3 & 24.8 & 16.5 & 9.9 & \\
\hline \multirow{2}{*}{$\begin{array}{l}\text { There are adequate support service in } \\
\text { credit /finance provision }\end{array}$} & Count & & 25 & 46 & 25 & 17 & 8 & 2.48 \\
\hline & $\begin{array}{l}\text { Row } \\
\text { N \% }\end{array}$ & Valid & 20.7 & 38.0 & 20.7 & 14.0 & 6.6 & \\
\hline \multirow{2}{*}{$\begin{array}{l}\text { There are adequate support service in } \\
\text { creating market linkage }\end{array}$} & Count & & 26 & 49 & 21 & 18 & 8 & 2.45 \\
\hline & $\begin{array}{l}\text { Row } \\
\text { N \% }\end{array}$ & Valid & 21.3 & 40.2 & 17.2 & 14.8 & 6.6 & \\
\hline \multirow{2}{*}{$\begin{array}{l}\text { SMEs have got all service at one stop } \\
\text { service center }\end{array}$} & Count & & 23 & 45 & 29 & 16 & 9 & 2.53 \\
\hline & $\begin{array}{l}\text { Row } \\
\text { N \% }\end{array}$ & Valid & 18.9 & 36.9 & 23.8 & 13.1 & 7.4 & \\
\hline \multirow{2}{*}{$\begin{array}{l}\text { There are adequate support service in } \\
\text { technology provision }\end{array}$} & Count & & 24 & 46 & 27 & 21 & 3 & 2.45 \\
\hline & $\begin{array}{l}\text { Row } \\
\text { N \% }\end{array}$ & Valid & 19.8 & 38.0 & 22.3 & 17.4 & 2.5 & \\
\hline \multirow[t]{2}{*}{ Committed of support SMEs } & Count & & 26 & 40 & 27 & 19 & 10 & 2.57 \\
\hline & $\begin{array}{l}\text { Row } \\
\text { N \% }\end{array}$ & Valid & 21.3 & 32.8 & 22.1 & 15.6 & 8.2 & \\
\hline \multirow[t]{2}{*}{ Procurement of capital goods are easy } & Count & & 28 & 44 & 18 & 24 & 8 & 2.51 \\
\hline & $\begin{array}{l}\text { Row } \\
\text { N \% }\end{array}$ & Valid & 23.0 & 36.1 & 14.8 & 19.7 & 6.6 & \\
\hline \multirow{2}{*}{$\begin{array}{l}\text { Easily to access information about } \\
\text { market }\end{array}$} & Count & & 31 & 39 & 25 & 22 & 5 & 2.43 \\
\hline & $\begin{array}{l}\text { Row } \\
\mathrm{N} \%\end{array}$ & Valid & 25.4 & 32.0 & 20.5 & 18.0 & 4.1 & \\
\hline \multirow[t]{2}{*}{ Easily acquisition of land or rent } & Count & & 29 & 40 & 26 & 22 & 2 & 2.39 \\
\hline & $\begin{array}{l}\text { Row } \\
\text { N \% }\end{array}$ & Valid & 24.4 & 33.6 & 21.8 & 18.5 & 1.7 & \\
\hline
\end{tabular}

There is no significant difference among the mean score of the indicators listed types of Challenges Faced by SMEs indicators. The whole indicators or their mean depicts that the respondents are indifferent between disagreeing and undecided on those issues listed as an indicator. Respondents were agreed that adequate support service to provide workplace, access to facilitate credit /finance ,established one-stop service center, technology transfer, the commitment of leaders to support SMEs, procurement of capital goods, easy access to information 
about market and acquisition of land /rent are the main challenge of economic integration for all SMEs in manufacturing subsector. To supplement the questioner an interview was held with SME leaders and stakeholders, and focus group discussion with SMEs councils. Accordingly, the result of the interviews and group discussions were agreed and approved themselves that the above-stated problems have been influencing the daily operation of SMEs activity. To that extent the training given to SMEs operators were not demand-based and adequate to fill their gap. This implies SMEs are working in difficult situation due to lack of commitment and weak support of the leaders and experts to mobilize and coordinate different stakeholders engage direct or indirect in SMEs activities.

The provision of land is problematic, the lease price of the land increases from 0.7 to 300 -birr $\mathrm{k} / \mathrm{meters}$ which is not affordable by SMEs and not considered the situation of the enterprises. Moreover, delay in the process and rent-seeking behavior due to lacks coordination and collaboration between SMEDA and Mekelle Municipality office. Further, lack of responsible and accountable officials in the public service.

The other critical challenge for SMEs if the financial regulation of the country which is not accessible to SMEs. SMEs are missed in the strategies. Evident shows that most of the SMEs take credit from informal institutions (local finance associations). Only one (6 million Birr) from small enterprise and five $(5,53.880,600$ birr) from medium enterprise were taken loan from development bank. While 29(17,371,698) small enterprises out of 945 small enterprises and 1(400,000) mediums out of 282 medium enterprises were got loan from and Kaza capital leasing in 2018/19.

Regarding the market linkage as we discussed above SMEs were mostly limited in the local market due to lack of quality and quantity input in the market that emanates from poor linkage with suppliers and lack of foreign currency for a quality product to compete in the market. Moreover, the product they are producing was not demanded in the international market due to a lack of quality. Only $43(5041,700)$ birr by small and $18(438067,313$ birr) export in 2018/19. The other problem was the political instability (peace and security) within and outside the country. As the operators explained some of ordered products are kept in the suppliers' store due to political instability in the country, SMEs were not move their products freely from one region to others. This implies SMEs are not access to market rather incurred additional carrying costs and capital tied up.

Table4.6 : Results from OLS estimation on determinants of integration

Integration (dependent Variables)

\begin{tabular}{|l|l|l|l|l|}
\hline Independent Variables & & correlation & Standard error & P-value \\
\hline Sex & male & $-0.403^{*}$ & -2.29 & 0.10 \\
\hline age & & $0.046^{*}$ & 0.41 & 0.10 \\
\hline Education & Higher & 0.222 & $1.29)$ & \\
\hline Business type & Leather product & 0.403 & $(1.64)$ & \\
\hline & Agroprosossing & 0.156 & $(0.63)$ & \\
\hline & Construction input & 0.333 & 0.01 & 0.10 \\
\hline & $\begin{array}{l}\text { Metal and } \\
\text { woodwork } 0.463^{*}\end{array}$ & 1.99 & 0.10 \\
\hline Enterprise type & Medium & $0.323^{*}$ & 1.99 & \\
\hline Policy and strategies & & 0.103 & 0.93 & 0.01 \\
\hline Enabling environment & & $0.323^{* * *}$ & 2.86 & 0.05 \\
\hline Competitiveness & & $0.285^{* *}$ & 2.23 & \\
\hline Support & & 0.00975 & 1.44 & \\
\hline Constant & 0.980 & 0.18 & 0.475 \\
\hline $\mathrm{N}$ & & 114 & & \\
\hline$R^{2}$ & & & & \\
\hline
\end{tabular}

Notes: the column is from OLS estimation. The $\mathrm{R}^{2}$ is $\mathrm{R}$-square for the model

The dependent variable is integration

The reference category for the sex dummy is female; the reference category for education is lower education; the reference category for the business type dummy is textile and garment; the reference category for enterprise type is small enterprise; Standard errors in parentheses, ${ }^{*} \mathrm{p}<0.1,{ }^{* *} \mathrm{p}<0.05,{ }^{* * *} \mathrm{p}<0.01$.

From table 2 above, the study shows that, enabling environment (EE)) have positive coefficient of correlation of 0.323 . The test for statistical significance of these coefficients shows that, p-value of 0.01 . Since 0.01 is less than $0.05(\mathrm{p}<0.05)$ then at $5 \%$ level of significance $(\alpha=0.05)$, there exists sufficient evidence to conclude that enabling environment is a predictor or influences the economic integration of SMEs in Tigray Mekelle city. However, the coefficient correlation of gender $=-0.403$, age 0.046 , and competitiveness $=0.285$ and the significant level of gender (0.10), age (0.10) and competitiveness $(0.05)$ then at $5 \%$ level of significance, it is conclusive that enabling environment alone no influence in determining the economic integration of Small and medium enterprises in the manufacturing sector.

Using the overall coefficients from table 4 above, the estimated equation is derived to be: $\mathbf{Y}=0.980+-$ 
$0.403 \mathrm{Ge}+0.046 \mathrm{Ag}+0.323 \mathrm{Ev}+0.285 \mathrm{Co}+$ e. where $\mathrm{Ge}=$ gender, $\mathrm{Ag}=\mathrm{age}, \mathrm{Ev}=$ enabling environment and $\mathrm{Co}$ $=$ competitiveness

This means that an improvement in creating conducive environment and support for SMEs will lead to strong economic integration of SMEs in the manufacturing sector and vice versa. Hence, the interpretation of the observed correlation is that economic integration of SMEs is significantly determined by enabling environment. A potential policy implication might be that it would be desirable to consider governments to improve supporting package, strengthen networking among actors and capacity building of operators and officials of SMEDA when redesigning the SMEs strategies in order to come true the economic integration of SMEs.

\section{Conclusion}

Most of $(71.9 \%)$ of the respondents were male indicates that there is a gap between the two genders that lack creating a favorable condition to enable women to participate in SME activities and share the benefit from the development opportunities even though the government policy clearly stated that priority given to women youth. With regard to their age , $58.3 \%$ of them were at age group of 30-49 years, Even though the government policies and strategies have emphasize to women and youth to engaged in SMEs, the result shows that most of the active group of the societies of both sexes do not benefit from the stated objective of the manufacturing and urban development.

As indicated in the level of education in the above in the result $30.2 \%$ have diploma This indicates most of the respondents had an educational background diploma. The sector could not absorb and create a job for the new blood graduated productive forces coming from different Universities to use new knowledge and technology. This should be further integrated into different development agenda since it is critical for the peace and security of the country. Motivate and aware to organize themselves based on their demand/willingness in an association to become benefit from credit facilities, provision of land and shads in the city.

$31.7 \%$ of the respondents said SMEs earn 501-1000 Birr Thus, the business cannot make a difference to change the living standard of the people, it is below the standard income per capita is $\$ 65$ per month. To triangulate this, result an interview was heled with SMEDA leaders. The result of the interviewed shows that most of SMEs were hiding their income in order avoid and evade tax. But data indicated from the profile of the SMESDA office the total capital of the 123 small enterprises start-up 348,940 and now it was growth to 40,564,241 birr out of this $3,196,700$ birr own and 272,700 from assistance and only 20,000birr were from loan . Whereas the 86 medium enterprise had started by 3,288,000 birr and increased to 32,100,000 birr .

$37.5 \%$ were engaged in metal and woodwork, The sector that dominates in the operation of the small and medium manufacturing enterprises is metal and woodwork and textile and garment, leather products the second and third place also goes to the construction manufacturing and geoprocessing sector respectively. This implies most of the SME engaged in metals and woodwork using past own experience and local skill and technology and focus on the local market. This implies the sector lacks scientific knowledge and skill to design and produce quality products compete in the international market. Concerning the source of funds to start-up business on the same table; most of $40.6 \%$ were from microfinance institutions and $39.6 \%$ their saving This shows that the main source of finance for SMEs in the city is from microfinance institutions and personal savings to start their business. The result from interviewee shows that access to finance from the government finical institutions is difficult and bureaucratic.

Most of the enterprises $71.9 \%$ is small manufacturing, this implies less attention and effort to initiate promote the small enterprises to come up and grow to the next stage and missed the middle elements to support. In addition to this the capital limit of the enterprises high and lack of team sprit to establish together. Due to their small size lack sound experiences and financial position are less capable of adjusting and carrying on successful businesses to upgrade to the next stage. Furthermore, prevent them from participating in the global market

\section{Policies and Strategies of Small and Medium Enterprises}

majority $46.7 \%$ of the respondents agreed that the strategies do not promote entrepreneur and human capital, productivity of SMEs and offer utmost attention to SME rather priority is given to micro, large enterprises, and foreign direct investment. Though policies and strategies are important to get out of poverty, it was not implementing properly due to lacks proper lack of scientific knowledge and skills to understand the federal strategies commitment of the leaders especially at the low-level position and experts to support and coordinate SMEs' activities. Additionally, the linkage of SMEs Strategy with other sectors are very poor even though the interest of the government is very high due to the lack of action of government officials and less effort by SMEs.

\section{Implementation of policies and strategies of SMEs in manufacturing sector Enabling Environment}

One of the roles of implementing strategy is creating a conducive working environment in which operators would grow and develop. The whole indicators or their mean depicts that the respondents are indifferent between disagreeing and undecided on those issues listed as an indicator. This implies that government cannot create enabling environment to understand the federal strategy to support implementors in the provision of access to finance, working place and market for SMEs operators. This can lead to low productivity and lack of completion 
in the market due to quality input and insufficient finance. Though the government designed strategy to support the small and medium enterprises, the result shows that the mean value below average and most of the respondents were agreed that no conducive environment was available for economic integration of SMEs created by the regional governments even though initiation is there. lacks commitment and serious attention in creating a conducive working environment and applied the best experience taken from other successful countries using the existing resources is low.

Problems were starting from the establishment of SMEs since no proper study was conducted before the SMEs are established. What are the criteria to establish; who support them? does the supporting unit have the capacity in knowledge, skill, and administrative system better than the SMEs? and does SMEs willing to work as a team or independent? The expert's knowledge and skills are not better than /below/ the SMEs operators. This situation makes the environment discouraging and implementers cannot strive with full potentials in promoting SMEs. Additionally, the role of leaders is limited with poor coordination of responsible sectors, improper functioning of the council, and lack of shared vision towards the role of SMEs providing a favorable working place and attractive market opportunity in creating a conducive working environment is weak. Leadership needed to fill the gaps in creating a conducive working environment.

\section{Competitiveness}

SMEs competitiveness can be enhanced with strategies including proximity to resources and suppliers, shared infrastructure and knowledge exchange (UN,2012), as the data shown, there is a statistically significant difference among the mean score of competitiveness factors all the results on the above table are below average 2.90. The respondents are indifferent between disagreeing and undecided on the rest of the indicators explained in the above. Countries like Ethiopia, available cheap and skilled labor for SMEs are obvious. SMEs cannot absorb the available workforces in the sector and pay less cost for human labors, in turn, increase productivity, On the other hand, SMEs were not produced a quality material compete in the international market due to lack of competitive strategies, quality and quantity inputs and government motivation at large. SMEs were always dependent on the government to arrange market and promote their product and prepare business cards and promote themselves and create a link with local and international markets. They limited in the local market due to lack of market assessment based on study knowing demanded products by the local and international markets. Moreover, the gap in technology transfer, capital, market linkage exposure to foreign market and management system since they used family employees. Further, unwillingness to take risk of producing quality products and fear of increasing cost of production and lack of internationalization outlook.

\section{Challenges of Economic Integration of SMEs in Manufacturing Sector}

There is no significant difference among the mean score of the indicators listed types of Challenges Faced by SMEs indicators. The whole indicators or their mean depicts that the respondents are indifferent between disagreeing and undecided on those issues listed as an indicator. Respondents were agreed that adequate support service to provide workplace, access to facilitate credit /finance ,established one-stop service center, technology transfer, the commitment of leaders to support SMEs, procurement of capital goods, easy access to information about market and acquisition of land /rent are the main challenge of economic integration for all SMEs. Accordingly, the result of the interviews and group discussions were agreed the above-stated problems have been influencing the daily operation of SMEs activity. To that extent the training given to SMEs operators were not demand-based and adequate to fill their gap. Thus,SMEs are working in difficult situation due to lack of commitment and weak support of the leaders and experts to mobilize and coordinate different stakeholders engage direct or indirect in SMEs activities.

The provision of land is problematic, the lease price of the land increases from 0.7 to 300 -birr $\mathrm{k} / \mathrm{meters}$ which is not affordable by SMEs and not considered the situation of the enterprises. Moreover, delay in the process and rent-seeking behavior due to lacks coordination and collaboration between SMEDA and Mekelle Municipality office. Further, lack of responsible and accountable officials in the public service. The other critical challenge for SMEs is the financial regulation of the country which is not accessible to SMEs. SMEs are missed in the strategies. Evident shows that most of the SMEs take credit from informal institutions (local finance associations). Only one (6 million Birr) from small enterprise and five (5,53.880,600 birr) from medium enterprise were taken loan from development bank. While 29(17,371,698) small enterprises out of 945 small enterprises and 1(400,000) mediums out of 282 medium enterprises were got loan from and Kaza capital leasing in 2018/19.

Regarding the market linkage as shown above SMEs were mostly limited in the local market due to lack of quality and quantity input in the market that emanates from poor linkage with suppliers and lack of foreign currency for a buying quality products to compete in the market. Moreover, the product they are producing was not demanded in the international market due to a lack of quality. Only 43(5041,700) birr by small and $18(438067,313$ birr) export in 2018/19. The other problem was the political instability (peace and security) within and outside the country. As the operators explained some of ordered products are kept in the suppliers' store due to political instability in the country, SMEs were not move their products freely from one region to others. SMEs are not access to market rather incurred additional carrying costs and their capital is tied up. 
The regression analysis shows that, enabling environment (EE) has positive coefficient of correlation of 0.323 . The test for statistical significance of these coefficients shows that, $p$-value of 0.01 . Since 0.01 is less than 0.05 (p $<0.05)$ then at $5 \%$ level of significance $(\alpha=0.05)$, there exists sufficient evidence to conclude that enabling environment is a predictor or influences the economic integration of SMEs in Tigray Mekelle city. However, gender, age, competitiveness of SMEs is not determined the integration of SMEs. Thus, the government policies and strategies could improve to create conducive environment, business development skill, access to finance and working promises by 32 percent working on the capability for SMEs to produce high quality product demanded by international market, design market strategy participate in the global market and linkage them with reliable suppliers.

\section{Recommendations}

Based on the findings and the knowledge acquired from the literature, recommendations are proposed to be carried out to resolve the challenges which are identified.

Re-orient and adjust the small and medium enterprise strategies and create conducive environment for the operation of SMEs operators.

Leaders should be committed and persistent in implementing and coordinating different activities related to economic integration among SMEs in the manufacturing sector.

Leaders should encourage and promote active involvement of SME council and proper coordination of stakeholders, private sectors, and emphasize capacity building and skill development of support providers(SMEs experts) and SMEs and close support, follow up and evaluation to towards improving the SMEs in the manufacturing sector

Small and medium enterprise development agency should aware SMEs that the benefit of integrating each other and organized in developmental circle and work together building team spirit to integrate complementary assets or investment to promote jointly with common resources.

The government should prepare the land and feasibility study on work premises, access to finance and infrastructure before establishing SMEs operators, and the lease price of land should consider SME operators' financial capacity.

The Regional government should establish a separate financial institution to facilitate SMEs' productivity and increase their competitiveness.

SMEs should create a strong relationship and networking with the region's large-scale enterprises and inputs suppliers through forward and backward linkage (subcontracting and outsourcing).

The training program should aim to enable potential SMEs, particularly youth and women to develop a sustainable business idea and SMEs startup.

The business operators should be ready for change and accept new technologies. The operators should create an ability of independence rather than waiting for another to offer them (be visionary, hard work and persistence)

The government of the country should call urgent political dialogue to settle the political instability within and the neighboring countries to get access free trade and market to enhance SMEs competitiveness.

\section{Reference}

ADB (2014): Support for Small and Medium-Sized Enterprises, 2005-2017: Business Environment, Access to Finance, Value Chains, and Women in Business, Linked Document, A Small and Medium-Sized Enterprises in Asia and the Pacific: Context and Issues

Amare Abawa(2017):Micro, Small and Medium Enterprises Development Strategies in Ethiopia: Retrospective and Prospective Analysis ;Mangalore University Department of Commerce Mangalore, India ,IRACST International Journal of Commerce, Business and Management (IJCBM), ISSN: 2319-2828 Vol. 6, No.1 JanFeb 2017

Amentie C, Negash E, Kumera L (2016) Barriers to Growth of Medium and Small Enterprises in Developing Country: Case Study Ethiopia Entrepreneurship Organize Manage

Amr Sadek(2013):Theories of Economic Integration: A Survey of the Economic and Political Literature Department of Econ omics, University of Wisconsin-Milwaukee, WI 53201, USA.

Belay File (2012): Determinants of Microenterprise Success in the Urban Informal tor of Addis Ababa a Multidimensional Analysis Netherlands ISBN 978-94-91478-05

Biru Ashenafi(2014):The Impact of Subsidy on the Growth of Small and Medium Enterprises (SMEs)De partment of Cooperative Studies, College of Business and Economics Mekelle University, Ethiopia. Journal of Economics and Sustainable www.iiste.org ISSN 2222-1700 (Paper) ISSN 2222-2855 (Online) Vol.5, No.3, 2014

CBC,2013: Unlocking the potential of the manufacturing sector in the COMESA region, A private sector position paper addressing the Constraints to Manufacturing Industry in COMESA region ,COMESA Business Council,Business Policy unit, July, 2013.Presented at the $1^{\text {st }}$ COMESA Manufacturer's Regional 
Dialogue,2013 Kigali, Rwanda

Central Statistical Authority (CSA) 2005/06. Report on Large and Medium Scale Manufacturing and Electricity Industries Survey. Vol. 321

Charles Harvies (2010): SMEs and Regional Production Networks, Centre for Small Business and Regional Research, School of Economics, Faculty of Commerce University of Wollongong, Australia p.16-42

Cibela Neagu(2016): The importance and role of small and medium-sized businesses; Theoretical and Applied Economics Volume 23 (2016), No. 3(608), Autumn, pp. 331- 338

Dawit Ayalew (2017): Economic Integration in East Africa: The Case of Ethiopia and Kenya Syracuse University June 2017 SURFACE Development

GSTS (2019) :Book of Conference Highlights of The $2^{\text {nd }}$ Grand Confernce of Global Society Of Tigran Scolars Towards Building Sustainable and Knowledge -Based Economy and Society in Tigrai $28^{\text {th }}$ July $-1^{\text {st }}$ August Mekelle ,Etiopia

Hagos (2012): Small and Medium Enterprise in Ethiopia: The Challenge and Prospects EKDI School of Public Policy and Management 2012 Capstone

Hosny, A.S. (2013) Theories of Economic Integration: A Survey of the Economic and Political Literature. International Journal of Economy, Management and Social Sciences Vol.2 No 5

ILO (2003): A Report on Micro and Small Enterprise Policy Review in Nepal

Marinov, V. (1999) Regional Economic Integration. PH Stopanstvo, Sofia. (in Bulgarian)

Mesfin Seyoum (2015): Challenges and Prospects of Small Enterprises in Ethiopia: A Study of Entrepreneurs in Tigray Region Submitted in accordance with the requirements for the degree of Doctorial of Philosophy in the Development Subject Development Studies at the University of South Africa October 2015

MoFED.(2006). Ethiopia: Building on Progress A Plan for Accelerated and Sustained Development to End Poverty (PASDEP), (2005/06-2009/10), September 2006, Addis Ababa.

MoUDH(2012):Government of the Federal Democratic Republic of Ethiopia Ministry of Urban Development and Housing SMEs Development and Strategies.

OECD (2018): Discussion Paper Small and Medium Enterprises Ministers Conference 22-23 February ,2018 Mexico City Enabling SMEs to scale up Plenary session 1

OECD, 2004: Conference of Ministers Responsible for Small and Medium-Sized Enterprises (SMEs): Promoting Entrepreneurship and Innovation SMEs in a Global Economy: Towards More Responsive and Inclusive Globalization Istanbul, Turkey 3-5 June 2004

Tsegay Hagos (2018) Ethiopian Herald report on SMEs Driving Force for Realizatio Renaissance, 22 April 2018 Ethiopia

Vugar Bayramov, Rashad Hasanov, Leyla Aghayarli, Zaur Kadyrov, Ismayil Aghahasanli, Sanan Isayev (2017) :A Comparative Study on Development of Small and Medium Enterprises (SMEs) in Azerbaijan

YaredTeshome, (2018) : Challenges and Opportunities of Micro and Small Enterprises Strategy in Ethiopia Urban development, the case of Ambo Town, Oromia, Ethiopia\# Mysore University, Institutes of Development Studies (IDS), Karnataka, India DMIMD Journal of Management Volume 9, Issue 1, March 2018 